
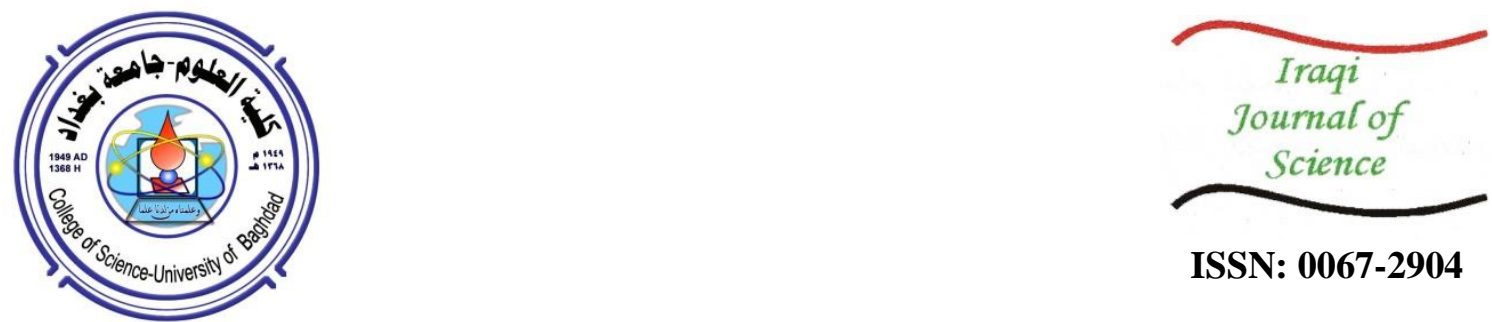

ISSN: 0067-2904

\title{
Comparison of LAMP and PCR for the Diagnosis of Methicillin-Resistance Staphylococcus Aureus (MRSA) Isolated from Different Food Sources
}

\author{
Sundus Ali Jassim ${ }^{1}$, Nuha Kandala ${ }^{2}$, Saad Sabah Fakhry ${ }^{1}$ \\ ${ }^{1}$ Food Contamination Researches Center, Ministry of Science \& Technology, Baghdad, Iraq \\ ${ }^{2}$ Department of Biotechnology, College of Science, University of Baghdad, Baghdad, Iraq
}

Received: $24 / 5 / 2020$

Accepted: 11/7/2020

\begin{abstract}
Staphylococcus aureus, which includes the methicillin-resistant $S$. aureus (MRSA), is a significant human pathogen producing different toxins and results in many different infection types, which include bacteremia, soft-tissue infections, as well as staphylococcal food poisoning. S. aureus is an important food-borne pathogen of humans due to ingestion of food containing enterotoxigenic strains. Detecting S. aureus fem A and mecA genes was evaluated with the use of a Loopmediated Isothermal Amplification Method (LAMP). The accuracy of this approach was similar to that attained using the approach of the conventional polymerase chain (PCR). Those two methods characterized 43 isolates of MRSA which were separated from different samples of foods and were not detected in the two other non-Staphylococcus strains (standard strains). The optimal temperature for the LAMP assay was $65^{\circ} \mathrm{C}$, with a detection limit of $2.5 \mathrm{ng} / \mu \mathrm{L}$ and $10^{3} \mathrm{cfu} / \mathrm{ml}$, when compared to $12.5 \mathrm{ng} / \mu \mathrm{L}$ and $10^{4} \mathrm{cfu} / \mathrm{ml}$ for PCR. The LAMP assay permits a onestep characterization of a specific gene, with no special equipment, and needs less time compared to the traditional PCR. It is assumed that the LAMP assay is a promising alternative method for the rapid identification of $S$. aureus and could be used in resource-limited laboratories and fields.
\end{abstract}

Keywords:-Staphylococcus aureus, Loop-mediated Isothermal Amplification (LAMP), femA and $m e c A$ genes.

\section{مقارنة طريقة تضخيم متساوي الحرارة و تفاعل سلسلة البلمرة التقليدية في تثخيص عزلات المكورات العنقودية الذهبية المقاومة للمثيسيلين والمعزولة من مصادر غذائية مختلفة}

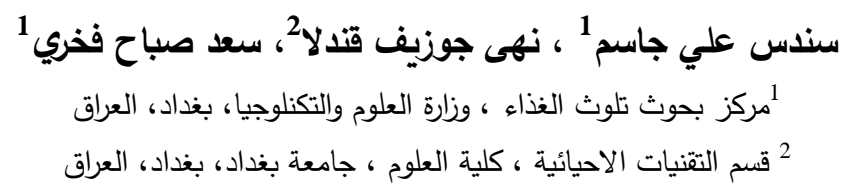

الخلاصة

تعد بكتريا المكورات العنقودية الذهبية من الممرضات المهمة التي تصيب البشر، خصوصا تلك المقاومة

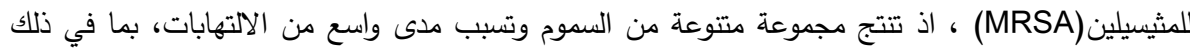

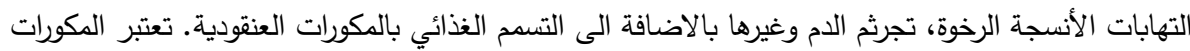

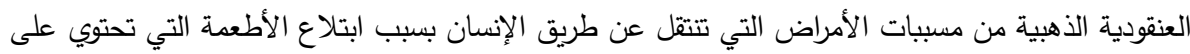

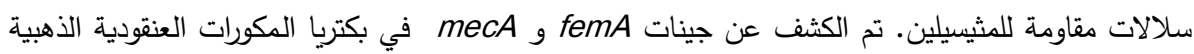

*Email: dr.sundusali@yahoo.com 


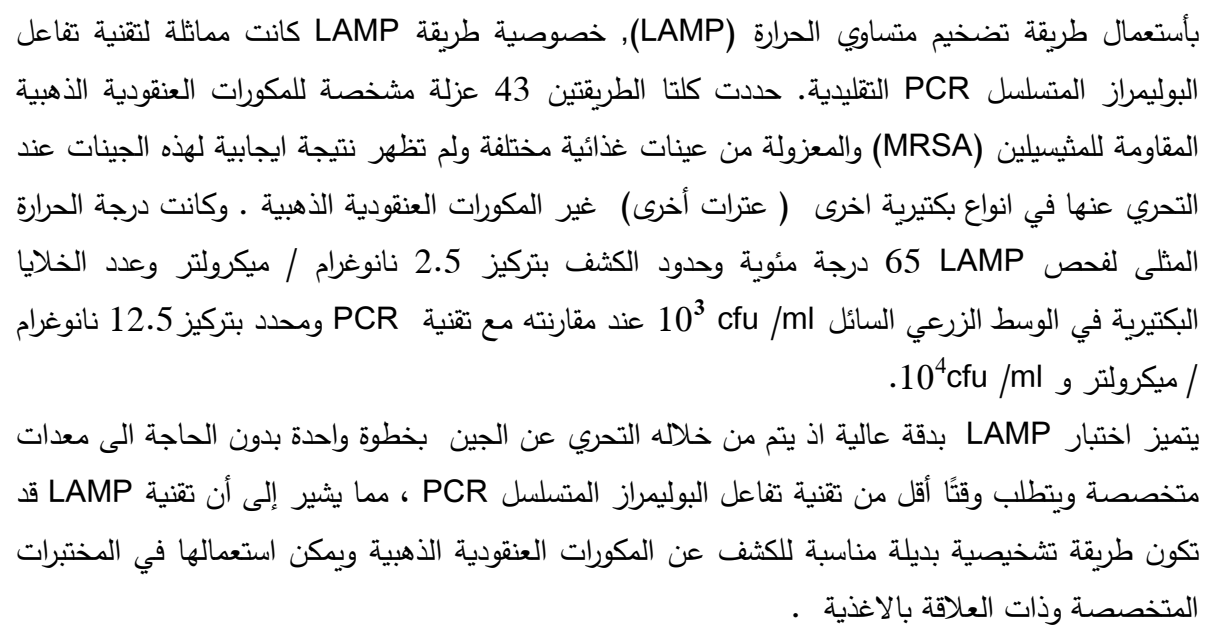

\section{INTRODUCTION}

Staphylococcus aureus is usually found to be tightly associated with humans; however, it can be detected as well in numerous parts of our environment, which include water, dust, feces, air, and clothing [1]. Numerous healthy people carry the $S$. aureus as a part of the normal microflora which is inhabiting the throat, nose, and skin, with nasal passage reported to harbor S. aureus in $10 \%$ to $50 \%$ of healthy populations [2].

S. aureus may be detected in several different types of food, which include mixed foods (such as salads and pasta), eggs and egg products, meats and meat products, baked goods, vegetables, and cheeses [3]. As a result of its virulence and multidrug resistance, S. aureus became one of the main concerns for food safety and public health in numerous countries [4- 8]. S. aureus that includes MRSA is one of the significant bacterial pathogens related to the health-care and community. They are producing various factors of virulence, which include toxic shock syndrome toxin (TSST) and staphylococcal enterotoxins (SEs), which are responsible for the staphylococcal food poisoning [9, 10]. A variety of rapid detection approaches were advanced to detect genes from S. aureus (MRSA). PCR technique has been proven as a beneficial tool for the reliable and fast detection of this type of genes $[11,12]$. On the other hand, this assay needs electrophoresis for the detection of the products of the amplified DNA, making it more time-consuming protocol. Even though the real-time PCR assay was implemented for the rapid detection of the $S$. aureus, the approach also needs costly equipment [13].

LAMP, that is a procedure based upon the auto-cycling strand displacement DNA synthesis with the use of Bst DNA polymerase enzyme, has been developed in the year 2000 [14]. Such Bst DNA polymerase was obtained from the Bacillus stearo-thermophilus, possessing 5'-3' exonuclease activities and requiring high magnesium concentration for the optimal activities [14]. This enzyme may undergo inactivation via the incubation for $15 \mathrm{~min}$ at $80^{\circ} \mathrm{C}$. In LAMP approach, 4 (F3, B3, BIP, and FIP) to 6 (F3, B3, BIP, FIP, Loop-R, and Loop-F, primers have been utilized for the amplifications, and the reactions have been performed at isothermal conditions [15, 16]. The Loop primers, binding to the loop structures, have been utilized for the purpose of shortening the LAMP assay's reaction time [17]. LAMP assay was advanced to rapidly identify a broad range of bacteria, which include S. aureus, Campylobacter jejuni, Vibrio parahaemolyticus, Leptospira species, Campylobacter coli, Escherichia coli, and Salmonella Typhi [18- 23]. Thus, this study aimed to verify the accuracy of LAMP assay in comparison with PCR technique for the molecular diagnosis of MRSA isolates.

\section{MATERIALS and METHODS}

\section{Bacterial isolates and references strains}

A total of 43 methicillin-resistant $S$. aureus isolates collected from 412 different food samples (meat, meat products, chicken products, dairy products, salads, and cakes) were included in the present study. Antibiotic susceptibility and phenotypic identification of the isolates were performed. The analysis findings were confirmed according to an earlier investigation [24]. All bacterial isolates were cultured on Brain Heart Infusion broth (BHI) (Oxoid/England) medium at $37^{\circ} \mathrm{C}$ for $18-24$ hours. 
Reference strains of S. aureus (Mu50 ATCC 700699) were utilized as positive control and Bacillus subtilis (PY 79) and Escherichia coli (DHa5) as negative control.

\section{DNA preparation for LAMP and PCR reaction}

A single colony of a bacterium was cultured in $5 \mathrm{ml}$ of BHI broth for $18 \mathrm{~h}-24 \mathrm{~h}$ and, after that, $1 \mathrm{ml}$ of the aliquot was centrifuged at $13,000 \mathrm{rpm}$ for $10 \mathrm{~min}$ at $4^{\circ} \mathrm{C}$. The bacterial cell pellet was suspended in $100 \mu \mathrm{l}$ of the Tris-EDTA (TE) and heated for $15 \mathrm{~min}$ at $95^{\circ} \mathrm{C}$. After centrifugation at $13,000 \mathrm{rpm}$ for 10 min, the supernatant was utilized as a DNA template source for the PCR and LAMP assays [25].

\section{Primer design for LAMP and PCR reaction}

The primers for $f e m A$ and $m e c A$ genes, respectively, were targeted in the LAMP assay according to [26], while the oligonucleotide primers for femA and mecA genes were designed based on the sequence for PCR reaction according to [27], as described in Table-1.

Table1-Base sequences of primers for the detection of $f e m A$ and $m e c A$ by PCR and LAMP.

\begin{tabular}{|c|c|c|c|}
\hline Gene & primer & Oligonucleotide sequence (5'---3') & References \\
\hline \multirow{6}{*}{$\begin{array}{l}\text { (LAMP) } \\
\text { femA }\end{array}$} & F3 & ATGCTGGTGGTACATCAA & \multirow{12}{*}{$\mathrm{Xu}$ et al., 2012} \\
\hline & B3 & TGGTTTAATAAAGTCACCAACAT & \\
\hline & BIP & $\begin{array}{l}\text { GGTCAATGCCATGATTTAATGCATAGCATTC } \\
\text { CGTCATTTTGCC }\end{array}$ & \\
\hline & FIP & $\begin{array}{l}\text { CAGAAGATGCTGAAGATGCTGGTCAATAATT } \\
\text { TCAGCATTGTAACC }\end{array}$ & \\
\hline & $\mathrm{LF}$ & AATCATTTCCCATTGCACT & \\
\hline & $\mathrm{LB}$ & TGTAGTTAAATTCAA & \\
\hline \multirow{6}{*}{$\begin{array}{l}\text { (LAMP)me } \\
\quad c A\end{array}$} & F3 & AAGATGGCAAAGATATTCAACT & \\
\hline & B3 & AGGTTCTTTTTTATCTTCGGTTA & \\
\hline & BIP & $\begin{array}{c}\text { GTGGATAGCAGTACCTGAGCCTTGATGCTAA } \\
\text { AGTTCAAAAGAGT }\end{array}$ & \\
\hline & FIP & $\begin{array}{l}\text { CCTCAAACAGGTGAATTATTAGCACCTTCGT } \\
\text { TACTCATGCCATAC } \\
\end{array}$ & \\
\hline & $\mathrm{LF}$ & TAATCATTTTTCATGTTG & \\
\hline & $\overline{\mathrm{LB}}$ & TGTAAGCACACCTTCATATGACGT & \\
\hline \multirow{2}{*}{$\begin{array}{l}\text { (PCR) } \\
\text { femA }\end{array}$} & $\mathrm{F}$ & AAAAAAGCACATAACAAGCG & \multirow{4}{*}{$\begin{array}{l}\text { Manisha et al., } \\
\quad 2000\end{array}$} \\
\hline & $\mathrm{R}$ & GATAAAGAAGAAACCAGCAG & \\
\hline \multirow{2}{*}{$\begin{array}{l}\text { (PCR) } \\
\text { mecA }\end{array}$} & $\mathrm{F}$ & ACTGCTATCCACCCTCAAAC & \\
\hline & $\mathrm{R}$ & CTGGTGAAGTTGTAATCTGG & \\
\hline
\end{tabular}

\section{LAMP assay}

LAMP assay for detecting S. aureus (MRSA) was carried out with the use of a group of three pairs of primers [26], as shown in Table1. LAMP reaction was performed in $25 \mu 1$ reaction mix, which is shown in Table-2. The negative control did not include any added DNA and DNA from each references strains Bacillus subtilis (PY79) and Escherichia coli (DH 25$)$. The positive control sample contained DNA of the $S$. aureus (Mu50 ATCC 700699). The reaction mix was incubated for 30min at $65^{\circ} \mathrm{C}$ in thermo mixer comfort (Germany/ Eppendorf) and the reaction was stopped at $80^{\circ} \mathrm{C}$ for $2 \mathrm{~min}$ [14]. Negative and positive results were distinguished through the observation of the white turbidity of the reaction mix. In the case of positive results, the products of amplification of the LAMP assay were stained by SYBR ${ }^{\circledR}$ Green dye $0.1 \%$ (U.S.A/ Promega), and then determined by both visual observation of the change of the color and an ultraviolet (UV) fluorescence (Eppendorf / Germany). 
Table 2-LAMP reaction mixture for detection of femA and mecA genes

\begin{tabular}{|c|c|c|}
\hline LAMP reaction mixture & DNA target detection & No template control (NTC) \\
\hline $\begin{array}{c}\text { Warm Start LAMP 2X Master } \\
\text { Mix }\end{array}$ & $12.5 \mu \mathrm{l}$ & $12.5 \mu \mathrm{l}$ \\
\hline Fluorescent dye(50x) & $0.5 \mu \mathrm{l}$ & $0.5 \mu \mathrm{l}$ \\
\hline LAMP Primer Mix (10x) & $2.50 \mu \mathrm{l}$ & $2.50 \mu \mathrm{l}$ \\
\hline Target DNA & $1 \mu \mathrm{l}$ & - \\
\hline $\mathrm{dH}_{2} \mathrm{O}$ & $8.5 \mu \mathrm{l}$ & $9.5 \mu \mathrm{l}$ \\
\hline Total Volume & $25 \mu \mathrm{l}$ & $25 \mu \mathrm{l}$ \\
\hline
\end{tabular}

\section{Detection of mecA and $f e m A$ genes using duplex PCR method}

The femA and mecA genes were amplified for identifying isolates of $S$. aureus (femA gene) and MRSA ( $m e c A$ gene). The oligonucleotide primers which are utilized for the amplification of the PCR for femA and $m e c A$ genes (Table-1) were designed based on sequences [27]. femA gene showed a yield of a 132 bp fragment, while mecA gene yielded a 163 bp fragment.

femA gene amplification was carried out in 35 cycles at $94^{\circ} \mathrm{C}$ initial denaturation for $5 \mathrm{~min}$, second denaturation for $1 \mathrm{~min}$ at $94^{\circ} \mathrm{C}$, primer annealing for $45 \mathrm{sec}$ at $60^{\circ} \mathrm{C}$, and DNA extension for $1.5 \mathrm{~min}$ at $72^{\circ} \mathrm{C}$. Whereas $m e c A$ gene was amplified in 35 cycles, with DNA denaturation for $1 \mathrm{~min}$ at $94^{\circ} \mathrm{C}$, primer annealing for $45 \mathrm{sec}$ at $54^{\circ} \mathrm{C}$, and DNA extension for $2 \mathrm{~min}$ at $72^{\circ} \mathrm{C}$. The PCR products were tested with agarose $(1.5 \% \mathrm{w} / \mathrm{v})$ gel electrophoresis for $1.5 \mathrm{hr}$ at $70 \mathrm{~V}$ in the presence of $100 \mathrm{bp}$ DNA ladder. DNA bands were visualized using UV transilluminator documentation system and photography. PCR amplification was performed in $25 \mu \mathrm{l}$, while the components used are shown in Table-3.

Table 3-PCR reaction mixture for $f e m A$ and $m e c A$ genes

\begin{tabular}{|c|c|c|}
\hline PCR reaction mixture & Final Concentration & Volume for one reaction $(\boldsymbol{\mu l})$ \\
\hline Sterile dd $\mathrm{H} 2 \mathrm{O}$ & & 4.5 \\
\hline $\begin{array}{c}\text { Green Master Mix (2X) } \\
\text { (U.S.A/ Promega) }\end{array}$ & $1 \mathrm{X}$ & 12.5 \\
\hline $\mathrm{MgCl}_{2}$ & $1 \mathrm{mM}$ & 1 \\
\hline Forward Primer & $0.20 \mu \mathrm{m}$ & 1 \\
\hline Reverse Primer & $0.20 \mu \mathrm{m}$ & 1 \\
\hline DNA & $0.20 \mu \mathrm{g}$ & 5 \\
\hline Final Volume reaction & & 25 \\
\hline
\end{tabular}

Determination of the accuracy of PCR and LAMP assays using bacterial cultures

S. aureus (Mu50 ATCC 700699) was cultured in BHI broth for $18 \mathrm{~h}$ at $37^{\circ} \mathrm{C}$ and a set of 10 -fold dilutions was performed in a solution of normal saline. The cell suspensions were centrifuged for 10

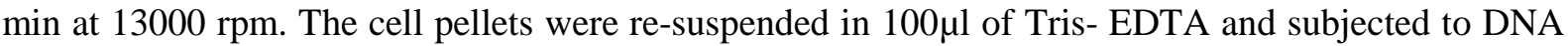
extraction for PCR and LAMP assays, as described earlier[25]. For the purpose of confirming the size of the inoculum, $0.1 \mathrm{ml}$ aliquot of every dilution of cell culture was plated onto Baird-parker agar (BPA) in duplicates. Following the incubation for $24 \mathrm{~h}$ at $37^{\circ} \mathrm{C}$, the number of the black shiny colonies with the clear areas surrounding the colonies was counted.

\section{RESULTS}

A total of 43 isolates of $S$. aureus (MRSA) and three reference strains were included in evaluating the specificity of PCR and LAMP assays for the detection of the femA and mecA genes of S. aureus. In the LAMP assay, negative and positive results were identified through the observation of white turbidity of reaction mix due to the precipitation of magnesium pyrophosphate, which is produced by auto-cycling reaction of the strand displacement, as illustrated in Figure-1.

Also, through the observation of the changes in the color by the naked eyes and the fluorescence under the ultra-violet light of the LAMP products which are stained by the SYBR Green dye, the orange color indicates a negative result, whereas the green color indicates a positive result. Very bright colors are determined as positive and the ones that lack the notable fluorescence are deemed to be negative, as showed in Figure-2.

Both LAMP and PCR methods correctly identified femA and mecA genes for 43 isolates of $S$. aureus and S. aureus strain (Mu50 ATCC 700699) and did not detect the other two reference strains Bacillus 
subtilis (PY79) and Escherichia coli (DHa5).

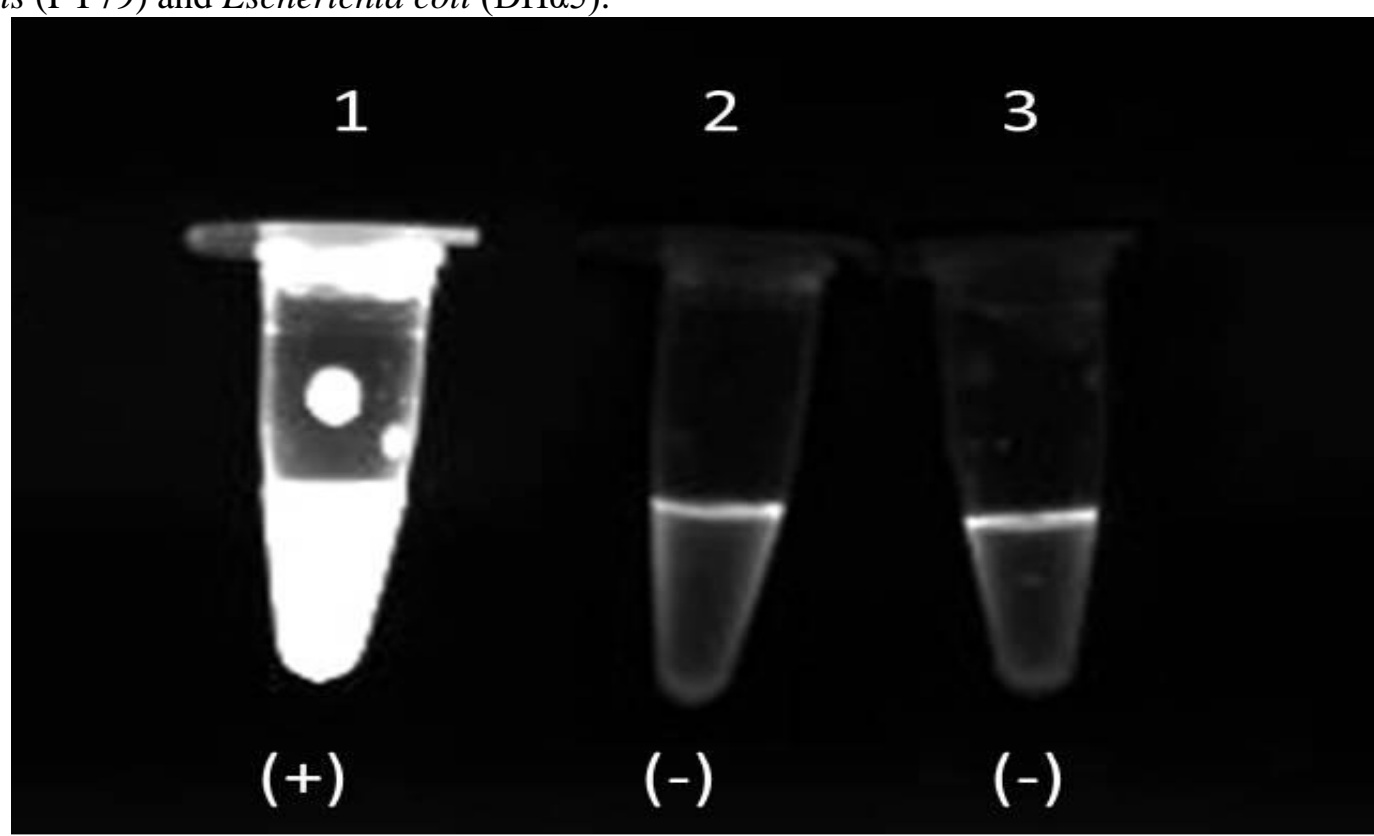

Figure 1-Amplification of LAMP products determined by visually detecting turbidity.

1- S. aureus (Mu50 ATCC 700699) positive.

2- Bacillus subtilis (PY79) negative.

3- Escherichia coli $(\mathrm{DH} \alpha 5)$ negative.
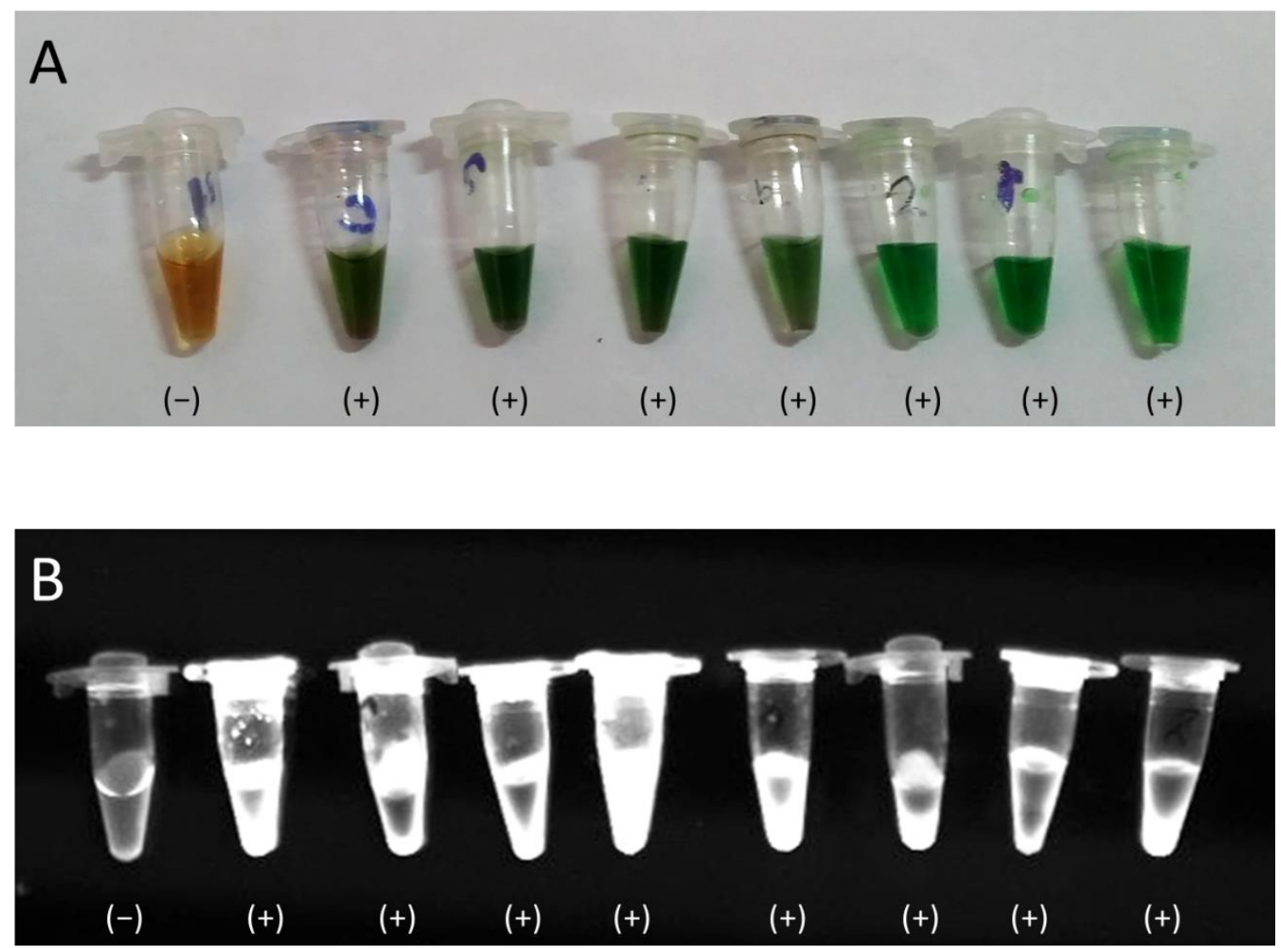

Figure 2-A- Amplification of the LAMP products dyed with SYBR Green and visually found through the examination of the color changes with the naked eyes:

- $\quad$ Orange points to the negative result.

- $\quad$ Green points to the positive result. 
B- Amplification of the LAMP products dyed with SYBR Green and visually found by fluorescence under the ultra-violet light:

Very bright ones indicate positive.

- The ones that lack the appreciable fluorescence indicate the negative.

PCR results in agarose gel electrophoresis of $S$. aureus (MRSA) used in this study are shown in Figure -3. The molecular detection for femA gene showed a band with a molecular fragment size of $132 \mathrm{bp}$, while the size was $163 \mathrm{bp}$ for $m e c A$ gene.

Detection limit results of the PCR and LAMP reactions with the use of the bacterial culture showed that the sensitivity of LAMP assay was $10^{3} \mathrm{cfu} / \mathrm{ml}$, whereas that of the PCR was $10^{4} \mathrm{cfu} / \mathrm{ml}$, as illustrated in Figures-(4a) and (4b).

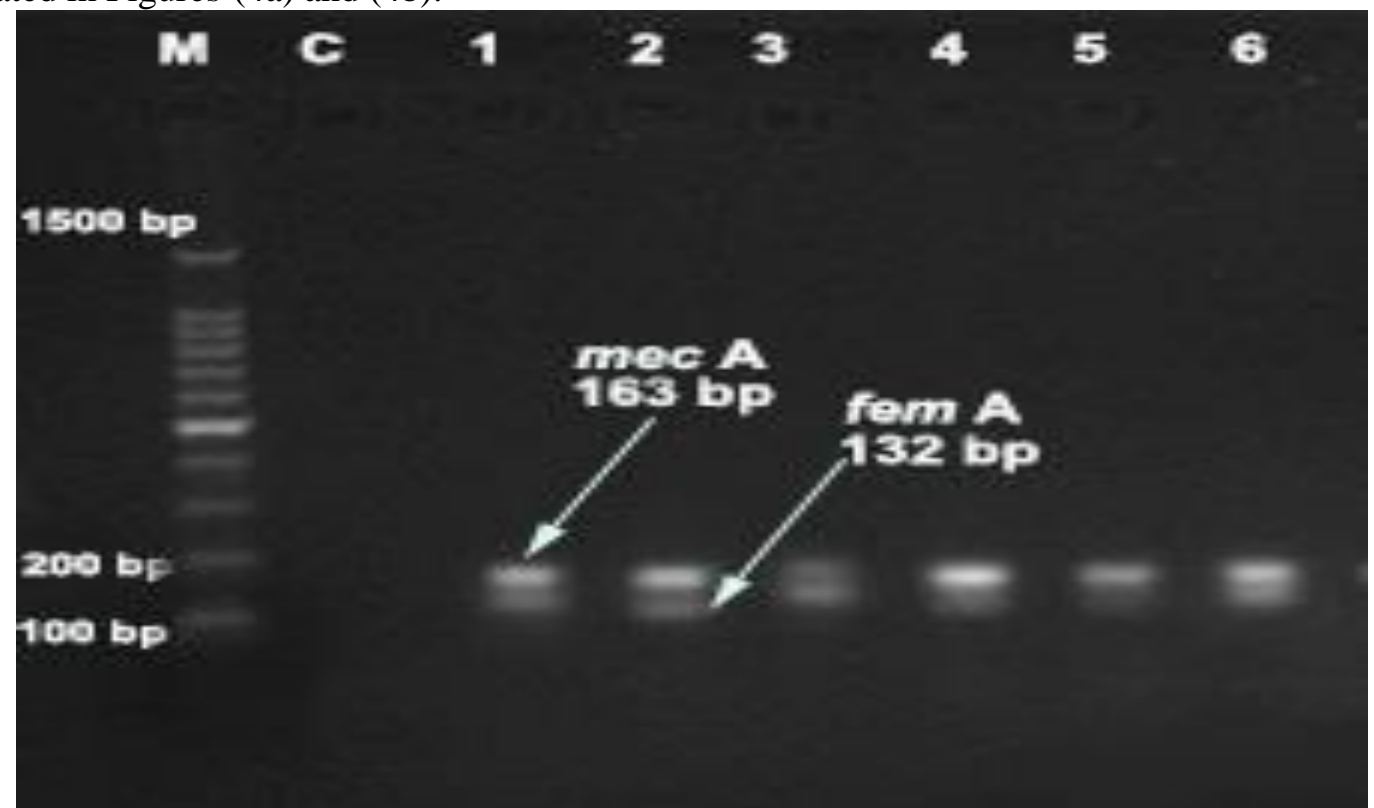

Figure 3-Agarose gel electrophoresis of PCR product of $S$. aureus (MRSA) used in this study (1.5 hour, 70V). Lane M=Marker, Lane $\mathrm{C}=$ control negative, Lanes (1-6)=femA and mecA positive $S$. aureus (MRSA).

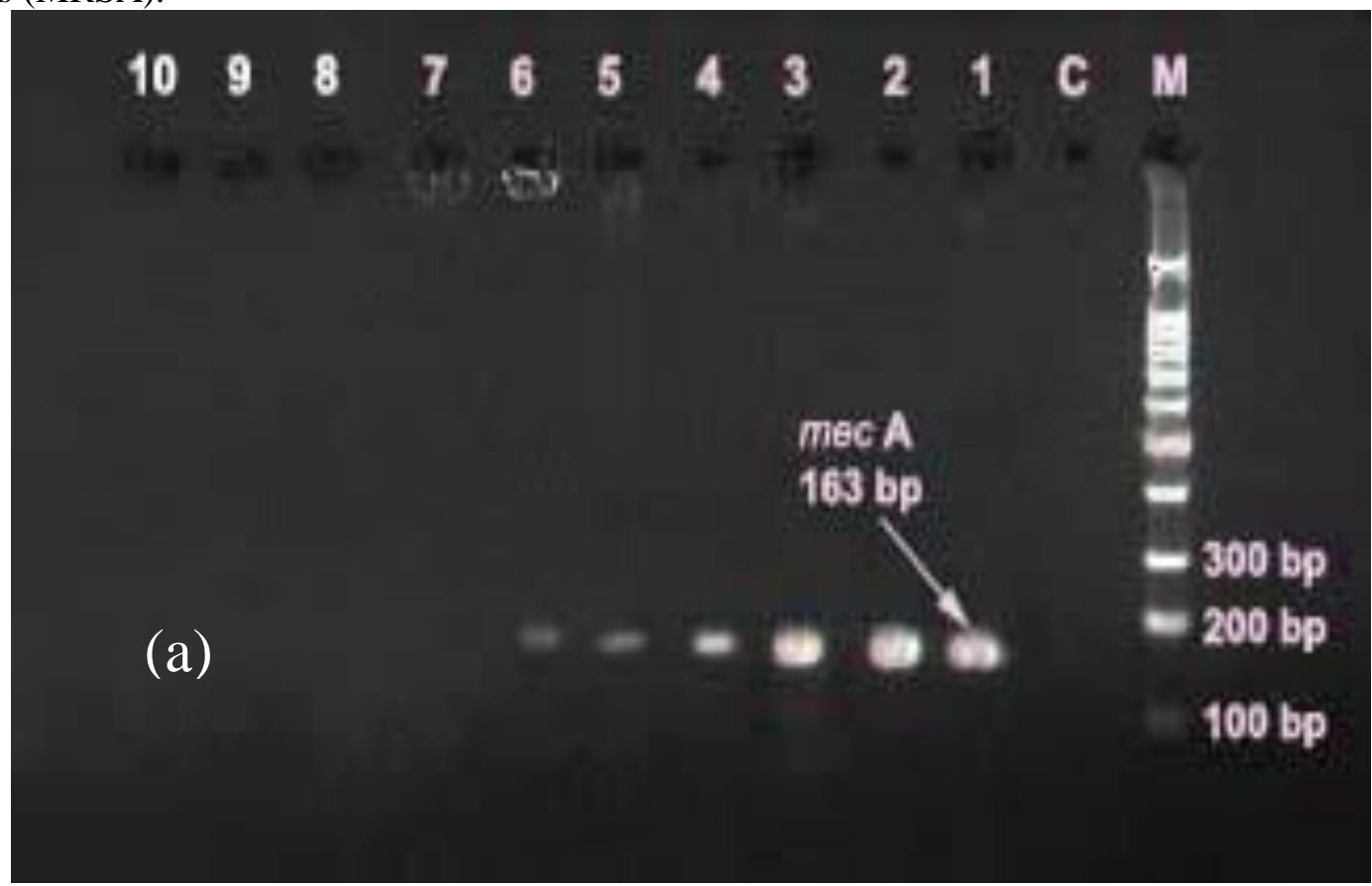

Figure 4a-Agarose gel electrophoresis of PCR from a variety of S. aureus (Mu50 ATCC 700699) concentration values. Lane $M=D N A$ ladder, lane $C=$ negative control, $1=10^{9} \mathrm{cfu} / \mathrm{ml}, 2=10^{8} \mathrm{cfu} / \mathrm{ml}$, $3=10^{7} \mathrm{cfu} / \mathrm{ml}, 4=10^{6} \mathrm{cfu} / \mathrm{ml}, 5=10^{5} \mathrm{cfu} / \mathrm{ml}, 6=10^{4} \mathrm{cfu} / \mathrm{ml}, 7=10^{3} \mathrm{cfu} / \mathrm{ml}, 8=10^{2} \mathrm{cfu} / \mathrm{ml}, 9=10 \mathrm{cfu} / \mathrm{ml}, 10=1$ $\mathrm{cfu} / \mathrm{ml}$. 


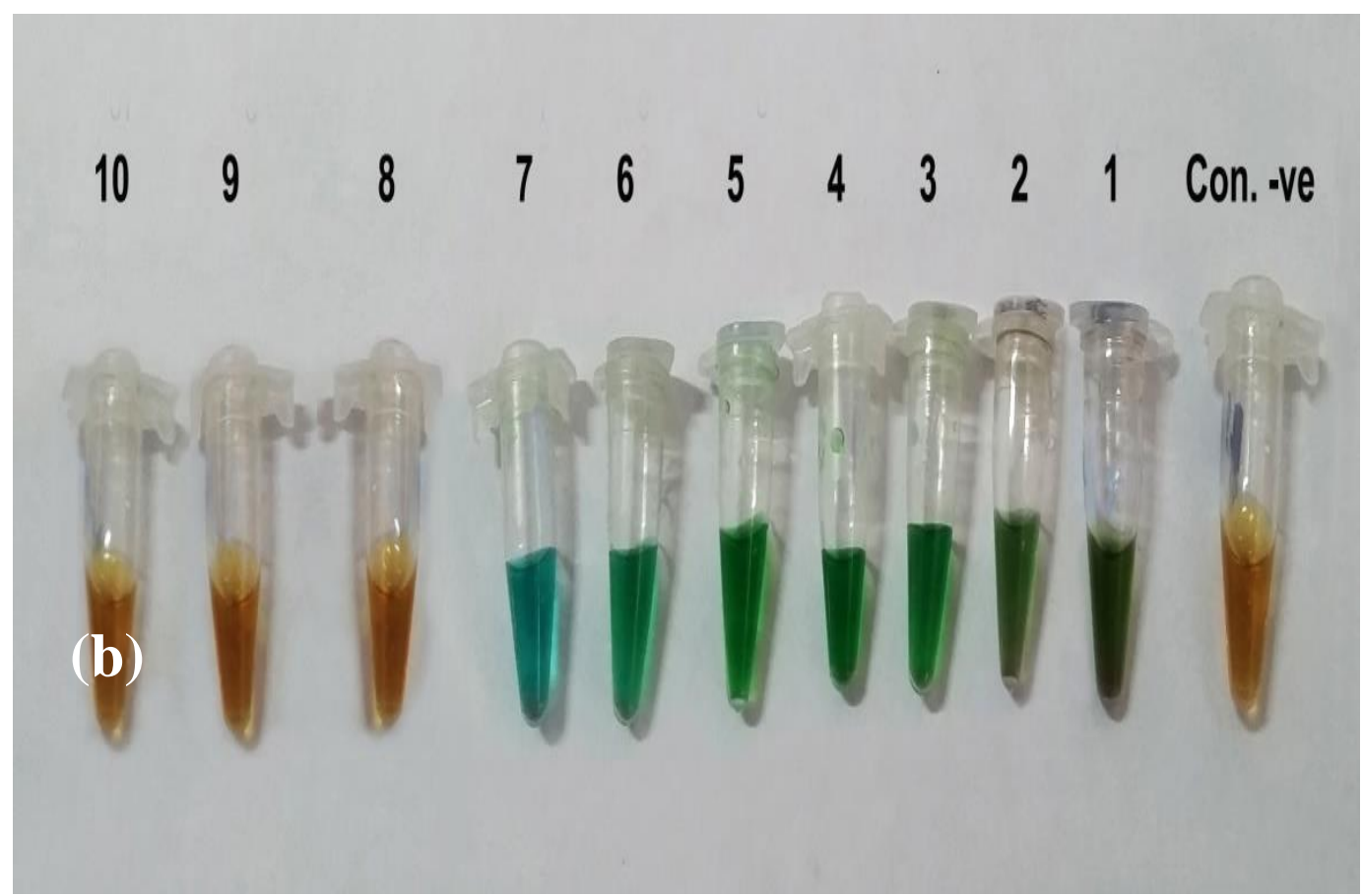

Figure 4b- LAMP products from a variety of $S$. aureus (Mu50 ATCC 700699) concentration values. $\mathrm{C}=$ negative control, $1=10^{9} \mathrm{cfu} / \mathrm{ml}, 2=10^{8} \mathrm{cfu} / \mathrm{ml}, 3=10^{7} \mathrm{cfu} / \mathrm{ml}, 4=10^{6} \mathrm{cfu} / \mathrm{ml}, 5=10^{5} \mathrm{cfu} / \mathrm{ml}, 6=10^{4} \mathrm{cfu} / \mathrm{ml}$, $7=10^{3} \mathrm{cfu} / \mathrm{ml}, 8=10^{2} \mathrm{cfu} / \mathrm{ml}, 9=10 \mathrm{cfu} / \mathrm{ml}, 10=1 \mathrm{cfu} / \mathrm{ml}$.

\section{Discussion}

S. aureus is presently a common food-borne pathogen worldwide and triggered high concern and interest due to their low detection level and association with antibiotic resistance. Therefore, precise and fast methods of detection are necessary to evaluate food and food products for the reduction of the risks of related food poisoning which results from contamination and infection by the food-borne pathogens.

MRSA is a very important bacterium that causes many different types of human infection [28]. Fast detection and confirmation of MSRA is significant for adequately and appropriately treating those infections, as well as infection and surveillance control. There is a small number of researches that use the LAMP assays to detect Staphylococcal isolate types, including mecA and femA genes from the isolates of the food [26].

In the present study, the accuracy of PCR and LAMP assays was determined using nonStaphylococcus reference stains: Bacillus subtilis (PY79) and Escherichia coli (DHa5). There were no false positive amplification observed, which indicates the accuracy of both methods, but accuracy of the LAMP approach was 10-fold higher than PCR technique for detecting the mecA and femA genes in S. aureus. The lower accuracy of PCR compared to that of LAMP can be a result of the existence of the inhibitors of PCR when the template DNA is not purified [29-31].

Compared with the time-consuming phenotypic approaches and the PCR which requires the thermal cycler as well as technical skills, the LAMP utilizes simple water bath and permits visually detecting the amplified products through fluorescence or turbidity. LAMP assay can be defined as a simpler and faster approach compared to the PCR. The entire time of amplification for the LAMP equals $60 \mathrm{~min}$, in comparison with that of the PCR that equals approximately $3 \mathrm{~h}-4 \mathrm{~h}$. The method is based upon the auto-cycling synthesis of the strand displacement DNA with the use of Bst DNA polymerase enzyme. It utilizes 6 primers that recognize 6 to 8 distinctive target gene regions, which facilitates detecting very minute target DNA quantities. Also, amplification takes place under the isothermal states [14, 32] and the loss of time because of the thermal variations is prevented [33]. Moreover, reaction is not inhibited with inhibitors present in the sample [34]. The product of the amplified gene may be observed by naked eyes, either through the turbidity as white precipitate or via a change in the color, utilizing fluorescent intercalating dyes (i.e. SYBR Green) [14]. LAMP assay results were compared to the conventional and phenotypic PCR, with the benefit of the LAMP assay 
of being fast, with a 90min turnaround time after isolating the organism from the specimen of the food. The method is cost effective as well. This is the reason why the LAMP was proved as one of the powerful tools that are beneficial in the detection, performing reliable virulence enterotoxin gene identifications of the pathogens from a variety of food sources, particularly for the resource-limited labs in the developing nations. For the routine uses in food analyses, approaches of the detection must be specific, simple, reliable, and robust. The options of the LAMP may be extended for the detection of the pathogens which exist in food samples, which reduces illness causing effects of food contamination as a result of time taken to identify them.

\section{CONCOLUSIONS}

This research has proven that the LAMP assay may be utilized as one of the fast molecular diagnostic assays to detect methicillin resistant $S$. aureus. It may be adapted easily in any of the microbiology laboratories as a rapid molecular assay, as a result of the fact that it is simple and easy to perform with no advanced instrumentations.

\section{REFERENCES}

1. Bergdoll, M. S. 1983. Enterotoxins. In: Easmon CSF, Adlam C, eds. Staphylococci and staphylococcal infection. London: Academic Press. 2: 559-598.

2. Genigeogis, C. A. 1989. Present state of Knowledge on staphylococcal intoxication. Int. Journal Food Microbiol. 9: 327-60.

3. Zeleny, R.; Emteborg, H. and Charoud-Got, J. 2015. Development of a reference material for Staphylococcus aureus enterotoxin A in cheese: feasibility study, processing, homogeneity and stability assessment. Food Chem. 168: 241-6.

4. Shin, E.; Hong, H. and Park, J. 2016. Characterization of Staphylococcus aureus fecal isolates associated with food-borne disease in Korea. Journal Appl. Microbiol. 121: 277-86.

5. Sheet, O. H.; Grabowaski, N. T. and Klein, G. 2016. Development and validation of a loop mediated isothermal amplification (LAMP) assay for the detection of Staphylococcus aureus in bovine mastitis milk sample. Mol. Cell Probes. 30: 320-5.

6. Lidiane, S. P., Rosângela, Z. M. and Joyce, B. A. L. 2017.Toxigenic Staphylococcus aureus in processing of coalho and mozzarella cheese. Afr. Journal Microbiol Res. 11: 521-9.

7. Jans, C.; Merz, A. and Johler, S. 2017. East and West African milk products are reservoirs for human and livestock-associated Staphylococcus aureus. Food Microbiol. 65: 64-73.

8. Miao, J., Liang, Y. and Chen, L. 2017. Formation and development of Staphylococcus biofilm: with focus on food safety. Journal Food Safety. 37: e12358.

9. Adwan, G. M., Abu-Shanab, B. A.; Adwan, K. M. and Jarrar, N. R. 2006. Toxigenicity of Staphylococcus aureus isolates from Northern Palestine. Emirates Medical Journal. 24(2): 127129.

10. Udo, E. E., Al-Mufti, S. and Albert, M. J. 2009. The prevalence of antimicrobial resistance and carriage of virulence genes in Staphylococcus aureus isolates from food handlers in Kuwait City restaurants. BMC Research Notes. 2. Article p108.

11. Tamaparu, S.; McKillip, J. and Drake, M. 2001. Development of a polymerase chain reaction assay for detection and differentiation of Staphylococcus aureus in dairy products. Journal Food Prot. 64: 664-8.

12. Ercolini, D., Blaiotta, G., Fusco, V. and Coppola, S. 2004. PCR-based detection of enterotoxigenic Staphylococcus aureus in the early stages of raw milk cheese making. Journal Appl. Microbiol. 96: 1090-6.

13. Klotz, M.; Opper, S.; Heeg, K. and Zimmermann, S. 2003. Detection of Staphylococcus aureus enterotoxins A to D by real-time fluorescence PCR assay. Journal clin. Microbiol. 41: 4683-7.

14. Notomi, T., Okayama, H., Masubuchi, H., Yonekawa, T., Watanabe, K., Amino, N. and Hase, T. 2000. Loop-mediated isothermal amplification of DNA. Nucleic Acids Res. 28: e63.

15. Yang, H., Ma, X., Zhang, X., Wang, Y. and Zhang, W. 2011. Development and evaluation of a Loop-mediated isothermal amplification assay for the rapid detection of Staphylococcus aureus in food. European Food Research and Technology. 232(5): 769-776.

16. Nagarajappa, S., Thakur, M. S. and Manonmani, H. K. 2011. Detection of enterotoxigenic staphylococci by Loop-mediated isothermal amplification method. Journal of Food Safety. 32(1): $59-65$. 
17. Nagamine, K.; Hase, T. and Notomi, T. 2002. Accelerated reaction by Loop-mediated isothermal amplification using loop primers. Molecular and Cellular Probes. 16(3): 223-229.

18. Yamazaki, W.; Taguchi, M. and Ishibashi, M. 2008. Development and evaluation of a Loopmediated isothermal amplification assay for rapid and simple detection of Campylobacter jejuni and Campylobacter coli. Journal of Medical Microbiology. 57(4): 444-451.

19. Hill, J., Beriwal, S. and Chandra, I. 2008. Loop-mediated isothermal amplification assay for rapid detection of common strains of Echerichia coli. Journal of Clinical Microbiology. 46(8): 28002804.

20. Sonthayanon, P., Chierakul, W. and Wuthiekanun, V. 2011. Accuracy of Loop-mediated isothermal amplification for diagnosis of human leptospirosis in Thailand. American Journal of Tropical Medicine and Hygiene. 84(4): 614-620.

21. Francois, P., Tangomo, M. and Hibbs, J. 2011. Robustness of a Loop-mediated isothermal amplification reaction for diagnosis applications. FEMS Immunology and Medical Microbiology. 62(1): 41-48.

22. $\mathrm{Xu}, \mathrm{Z}$; $\mathrm{Li}$, L. and Chu, J. 2011. Development and application of Loop-mediated isothermal amplification assay on rapid detection of various types of staphylococci strains. Food Research International. 47(2): 166-173.

23. Wang, L., Zhao, X. and Chu, J. 2011. Application of an improved loop-mediated isothermal amplification detection of Vibrio parahaemolyticus from various seafood samples. African Journal of Microbiology. 5(31): 5765-5771.

24. Jassim ,S.A..Kandala, N.J. and Abdullah, T.S. 2020. Molecular Detection of Enterotoxins Genes of Multiresistant Staphylococcus aureus Isolates from Different Sources of Food. Iraqi Journal of Science. 62(1).

25. Reischl, U., Lindle, H. J., Metz, M., Leppmeier, B. and Lehn, N. 2008. Rapid identification of methicillin-resistant Staphylococcus aureus and simultaneous species confirmation using real-time fluorescence PCR. J. Clin. Mocrobiol. 38: 2429-33.

26. Xu, Z., Li, L., Chu, J., Peters, B., Harris, M. and Li, B. 2012. Development and application of loop-mediated isothermal amplification assays on rapid detection of various types of Staphylococci strains. Food Res. Int. 47: 166-73.

27. Manisha M., Gehua W. and Wendy M. J. 2000. Multiplex PCR for Detection of Genes for Staphylococcus aureus Enterotoxins, Exfoliative Toxins, Toxic Shock Syndrome Toxin 1, and Methicillin Resistance. Journal of Clinical Microbiology. 38(3): 1032-1035.

28. David, M. Z. and Daum, R. S. 2010. Community-associated methicillin-resistant Staphylococcus aureus: epidemiology and clinical consequences of an emerging epidemic. Clin.Microbiol.Rev. 23: 616-87.

29. Kaneko, H., Kawana, T., Fukushima, E. and Suzutani, T. 2007. Tolerance of loop-mediated isothermal amplification to a culture medium and biological substance. J. BiochemBiophys Methods. 70: 499-501.

30. Okada, K., Chantaroj, S. and Taniguchi, T. 2010. A rapid, simple and sensitive loop-mediated isothermal amplification method to detect toxigenic Vibrio cholera in rectal swab samoles. DiagnMicrobiol Infect Dis. 66: 135-9.

31. Karanis, P., Thekisoe, O., Kiouptsi, K., Ongerth, J., Igarashi, I. and Inoue, N. 2007. Development and preliminary evaluation of a loop-mediated isothermal amplification procedure for sensitive detection of Cryptosporidium Oocystes in fecal and water samples. Appl. Environ Microbiol. 73: $5660-2$.

32. Zhao, X., Li, Y., Park, M., Wang, J., Zhang, Y. and He, X. 2013. loop-mediated isothermal amplification assay targeting the femA gene for rapid detection of Staphylococcus aureus from clinical and food samples. J. Microbiol Biotechnol. 23: 246-50.

33. Lim, K. T., The, C. S. and Thong, K. L. 2013. Loop-mediated isothermal amplification assay for the rapid Detection of Staphylococcus. Biomed Res. Int. 10: 1-5.

34. Tomita, N., Mori, Y., Kanda, H. and Notomi, T. 2008. Loop-mediated isothermal amplification (LAMP) of gene sequences and simple visual detection of products. Nat. Protoc. 3: 877-92. 